\title{
Soil compaction management and soybean yields with cover crops under no-till and occasional chiseling
}

\author{
Juliano C. Calonego*, Juan P.A. Raphael, João P.G. Rigon, Leontino de Oliveira Neto, \\ Ciro A. Rosolem
}

Department of Crop Science, College of Agricultural Sciences, São Paulo State University, José Barbosa de Barros Street, 1780, 18610-307, Botucatu, São Paulo, Brazil

\section{A R T I C L E I N F O}

\section{Article history:}

Received 12 September 2016

Received in revised form 3 February 2017

Accepted 4 February 2017

Available online 11 February 2017

\section{Keywords:}

Agricultural management

Crop rotation

Land use effects

Soil physical proprieties

No-till

Soil use and management

\begin{abstract}
A B S T R A C T
The introduction of cover crops in agricultural systems under no-till is important in soil structuring and remediation. However, there is a lack of studies exploring the effects of cover crops compared with other soil compaction control tools, such as chiseling, in the long term, mainly under tropical climates. This study aimed to evaluate soil physical properties by cover crops and chiseling in a compacted soil, as well as its effects on soybean yields. The experiment was conducted in Botucatu, Brazil, under no-till. Three crops were grown per year. Soybean [Glycine max (L.) Merrill] was cropped as summer crop in rotation with triticale (X Triticosecale Wittmack) or sunflower [Helianthus annuus (L.)] as fall/winter crop. In spring, three different cover crops were grown, pearl millet [Pennisetum glaucum (L.) R. Brown], forage sorghum [Sorghum bicolor (L.) Moench] and sunn hemp [Crotalaria juncea (L.)], compared to a fallow treatment, which was chiseled in 2003, 2009 and 2013 only, always in October and down to $0.60 \mathrm{~m}$ depth. The first chiseling increased soil macroporosity and soybean yields in the immediate cropping season (2003/2004). However, these benefits were short-lived and in two years the use of cover crops resulted in higher yields. In the long-term, cover crops improve soil structure, with equal or better results than those obtained by occasional chiseling, as an increase in soil macroporosity by sunn hemp up to $0.20 \mathrm{~m}$ depth and a decrease in soil bulk density by sunn hemp and pearl millet in the $0.40-0.60 \mathrm{~m}$ layer. Among the cover crops, sunn hemp is particularly interesting, because it increases macroporosity in clay soils otherwise with limited aeration and increases the soybean yield.
\end{abstract}

(C) 2017 Published by Elsevier B.V.

\section{Introduction}

Compacted layers develop in agricultural soils as a result of external pressures from machines or animals, or it may be a natural process of accommodation of soil particles (Hamza and Anderson, 2005). As soil bulk density increases and total porosity decreases, soil resistance to root penetration increases, posing an impediment to root growth and restricting water and air movement throughout the profile (Chen et al., 2014), resulting in poor aeration of the root system (Marschner, 1995). Water infiltration is hindered and runoff increases resulting in water and soil loss, leading to the impoverishment of the topsoil. When growing roots encounter a high

\footnotetext{
* Corresponding author.

E-mail addresses: juliano@fca.unesp.br, julianocarloscalonego@gmail.com (J.C. Calonego), juanpiero1@gmail.com (J.P.A. Raphael), jprigon@fca.unesp.br (J.P.G. Rigon), leontino-neto@hotmail.com (L.d. Oliveira Neto), rosolem@fca.unesp.br (C.A. Rosolem).
}

resistance layer in the soil profile, they proliferate in the uppermost soil layer, which is quickly depleted in water and nutrients (Soane and van Ouwerkerk, 1995), thus resulting in yield loss. Therefore, soil compaction effects on crop yield are magnified in low rainfall years (Calonego and Rosolem, 2010).

Although mechanical methods used to remediate soil compaction, such as chiseling, improve soil physical conditions, they have ephemeral effects (Busscher et al., 2002). In the medium- and long-term, significant benefits can be seen in soil structure with no-till (NT) and the use of cover crops with aggressive root systems (Calonego and Rosolem, 2008). Some forage grasses, such as brachiaria, pearl millet, sorghum, sorghum-sudangrass, and finger millet have large root systems with high ability to explore the soil profile. In contrast, species with taproot systems, such as pigeon pea, sunn hemp, and radish have fewer roots, but they have greater ability to break through compacted soil layers (Rosolem et al., 2002). Garcia et al. (2012) noted growing sorghum-sudangrass and pearl millet, compared with fallow, resulted in higher porosity (total, macro and micro), lower bulk density and higher number 
Table 1

Rainfall and average temperature during ten soybean seasons (from December to March). Botucatu, Brazil.

\begin{tabular}{|c|c|c|c|c|c|c|c|c|c|}
\hline $2003 / 04$ & $2004 / 05$ & $2005 / 06$ & $2006 / 07$ & $2009 / 10$ & $2010 / 11$ & $2011 / 12$ & $2012 / 13$ & $2013 / 14$ & $2014 / 15$ \\
\hline \multicolumn{10}{|c|}{ Rainfall (mm) } \\
\hline 770 & 767 & 829 & 751 & 997 & 1094 & 726 & 1239 & 359 & 1037 \\
\hline \multicolumn{10}{|c|}{ Average temperature $\left({ }^{\circ} \mathrm{C}\right)$} \\
\hline 21.1 & 21.6 & 21.4 & 20.2 & 23.0 & 23.9 & 24.6 & 24.3 & 24.8 & 23.2 \\
\hline
\end{tabular}

of aggregates larger than $2 \mathrm{~mm}$ in the layer $0-0.10 \mathrm{~m}$; on the other hand, sunn hemp presented intermediate values, resulting in lower bulk density and higher macroporosity compared with fallow.

Cover crops with extensive, aggressive root systems help in the formation of soil aggregates, thereby facilitating root growth of succeeding crops and higher water infiltration. Soil aggregation is usually improved by management systems including crops with high ability to form roots and increase soil organic matter (SOM) (Castro et al., 2011). The contribution of SOM in the formation of stable aggregates is attributed to processes such as the formation of cationic bridges, cementation between particles, and stability promoted by root and microbial exudates around and within aggregates (Castro et al., 2015; Tisdall and Oades, 1982). Therefore this could be a mechanism whereby the use of cover crops in rotation with the main crop would have a long-lasting effect on alleviating soil physical limitations.

The objective of this study was to evaluate, in a compacted clay soil, the changes in physical properties and its influence on soybean grain yield as affected by cover crops and chiseling in a long-term experiment.

\section{Materials and methods}

\subsection{Experimental site and treatments}

The experiment was carried out in Botucatu, São Paulo, Brazil $\left(22^{\circ} 49 \mathrm{~S}, 48^{\circ} 25^{\prime} \mathrm{W}\right.$ altitude: $786 \mathrm{~m}$ ). The climate is mesothermal with dry winters, and the dry season is well defined from May to September, with yearly average rainfall of $1450 \mathrm{~mm}$, distributed mostly between October and April. Average temperatures and total rainfall during 10 soybean seasons (from December to March) are shown in Table 1. The soil is a clay Typic Rhodudalf(Soil Survey Staff, 2014). Before starting the experiment (April 2003), the soil was sampled for chemical (Raij et al., 2001), physical and granulometric (Embrapa, 1997), and aggregate stability (Kemper and Chepil, 1965) analysis (Table 2). The soil physical characterization showed the presence of compacted soil, mainly in the $0.10-0.20 \mathrm{~m}$ layer, which limits the root growth of soybean (Rosolem and Calonego, 2010).

The experiment has been conducted since 2003 with triticale (X Triticosecale Wittmack) and sunflower [Helianthus annuus (L.)] grown in the fall/winter, followed by pearl millet [Pennisetum glaucum (L.)], forage sorghum [Sorghum bicolor(L.) Moench], sunn hemp [Crotalaria juncea (L.)], and fallow/chiseling in the spring (Table 3). The assigned plots were chiseled in 2003,2009 and 2013 just before soybean [Glycine $\max (\mathrm{L}$.) Merrill] planting. Soybean was grown in the summer. The experimental design was a randomized block with split plots, with four replications and eight treatments. Treatments consisted of grain crops (triticale or sunflower) grown in the fall/winter as main plots (plots with $256 \mathrm{~m}^{2}$ ) and cover crops (pearl millet, forage sorghum or sunn hemp) or fallow/chiseling as subplots in spring (subplots with $40 \mathrm{~m}^{2}$ ). Crop rotations were repeated annually (Table 3 ). Triticale and sunflower were planted without fertilizer, at row spacings of 0.17 and $0.51 \mathrm{~m}$, respectively, using $165 \mathrm{~kg} \mathrm{ha}^{-1}$ of triticale seeds and $22 \mathrm{~kg} \mathrm{ha}^{-1}$ of sunflower seeds. The fall/winter crops were sown each year in the second half of April and harvested from the second week of August to the first week of September, using a plot harvester. The spring cover crops
Table 2

Selected chemical, physical, granulometric and aggregate stability properties of the soil before the experiment was started (April 2003). Botucatu, Brazil.

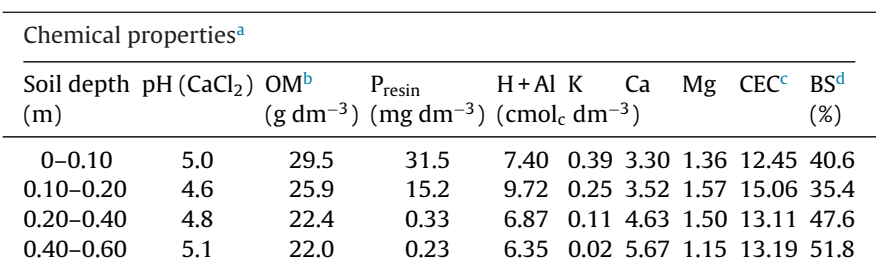

Physical properties

\begin{tabular}{|c|c|c|c|c|c|c|}
\hline & \multirow[t]{2}{*}{$P R^{f}$} & \multirow[t]{2}{*}{ Moisture $^{g}$} & \multirow[t]{2}{*}{ Bulk density } & \multicolumn{3}{|c|}{ Porosity } \\
\hline & & & & Total & Macro & Micro \\
\hline$(\mathrm{m})$ & (MPa) & $\left(\mathrm{gg}^{-1}\right)$ & $\left(\mathrm{g} \mathrm{cm}^{-3}\right)$ & \multicolumn{3}{|c|}{$\left(\mathrm{m}^{3} \mathrm{~m}^{-3}\right)$} \\
\hline $0-0.10$ & 2.1 & 0.29 & 1.31 & 0.55 & 0.10 & 0.42 \\
\hline $0.10-0.20$ & 2.5 & 0.34 & 1.38 & 0.52 & 0.07 & 0.45 \\
\hline $0.20-0.40$ & 2.3 & 0.38 & 1.29 & 0.50 & 0.05 & 0.45 \\
\hline $0.40-0.60$ & 1.8 & 0.42 & 1.31 & 0.58 & 0.05 & 0.48 \\
\hline
\end{tabular}

Granulometry

\begin{tabular}{cccc}
\hline & Sand & Clay & Silt \\
\cline { 2 - 4 }$(\mathrm{m})$ & $\left(\mathrm{g} \mathrm{kg}^{-1}\right)$ & & \\
\hline $0-0.10$ & 134 & 584 & 282 \\
$0.10-0.20$ & 128 & 599 & 273 \\
$0.20-0.40$ & 110 & 645 & 246 \\
$0.40-0.60$ & 88 & 715 & 197
\end{tabular}

Soil aggregate stability ${ }^{\mathrm{h}}$

\begin{tabular}{lcccc}
\hline & Aggregates $^{\mathrm{i}}$ & MWD $^{\mathrm{j}}$ & $\mathrm{GMD}^{\mathrm{k}}$ & ASI $^{\mathrm{l}}$ \\
\cline { 2 - 5 }$(\mathrm{m})$ & $\left(\mathrm{g} \mathrm{g}^{-1}\right)$ & $(\mathrm{mm})$ & $(\mathrm{mm})$ & $\%$ \\
\hline $0-0.10$ & 0.39 & 1.86 & 2.53 & 93.64 \\
\hline
\end{tabular}

a Raij et al. (2001).

b Organic matter.

c Cation exchange capacity.

d Soil base saturation.

e Embrapa (1997).

f Penetrometer resistance.

g Soil moisture at the time of PR determination.

h Kemper and Chepil (1965).

i Aggregates $>2 \mathrm{~mm}$.

j Mean weight diameter.

k Geometric mean diameter.

${ }^{1}$ Aggregate stability index.

were sown in the first half of October, in rows spaced of $0.17 \mathrm{~m}$ from each other. We used 25,30 , and $15 \mathrm{~kg} \mathrm{ha}^{-1}$ of seeds of pearl millet, sorghum, and sunn hemp, respectively. In the first half of December, around 60 days after planting, the spring cover crops were chemically desiccated with glyphosate at $2.5 \mathrm{~kg} \mathrm{ha}^{-1}$ (a.i.), and then soybean was planted in rows $0.45 \mathrm{~m}$ apart, targeting a population of 300,000 plants ha ${ }^{-1}$. Each year soybean seeds were inoculated with Bradyrhizobium sp. and fertilized with $50 \mathrm{~kg} \mathrm{ha}^{-1} \mathrm{~K}$ and $26 \mathrm{~kg} \mathrm{ha}^{-1} \mathrm{P}$, as potassium chloride and triple superphosphate, respectively, at the sowing time, $0.05 \mathrm{~m}$ below and beside the seeds and with fertilizer seeder equipment. The spring cover crop species 
Table 3

Crop sequences used in the experiment since 2003. Botucatu, Brazil.

\begin{tabular}{|c|c|c|}
\hline Fall/winter (plots) & Spring (subplots) & Summer (total area \\
\hline Triticale $^{\mathrm{a}}$ & Pearl millet ${ }^{\mathrm{c}}$ & Soybean $^{\mathrm{f}}$ \\
\hline Triticale & Forage sorghum $^{\mathrm{d}}$ & Soybean \\
\hline Triticale & Sunn hemp & Soybean \\
\hline Triticale & Fallow/chiseling ${ }^{g}$ & Soybean \\
\hline Sunflower ${ }^{\mathrm{b}}$ & Pearl millet & Soybean \\
\hline Sunflower & Forage sorghum & Soybean \\
\hline Sunflower & Sunn hemp & Soybean \\
\hline Sunflower & Fallow/chiseling & Soybean \\
\hline \multicolumn{3}{|c|}{ a X Triticosecale Wittmack. } \\
\hline \multicolumn{3}{|c|}{ b Helianthus annuus (L.). } \\
\hline \multicolumn{3}{|c|}{ c Pennisetum glaucum (L.). } \\
\hline \multicolumn{3}{|c|}{ d Sorghum bicolor (L.) Moench. } \\
\hline \multicolumn{3}{|c|}{ e Crotalaria juncea(L.). } \\
\hline \multicolumn{3}{|c|}{ f Glycine $\max (\mathrm{L}$.$) Merrill.$} \\
\hline $\mathrm{g}$ Chiseling in 2003 & 013. & \\
\hline
\end{tabular}

were fertilized at planting with $40 \mathrm{~kg} \mathrm{~N} \mathrm{ha}^{-1}$ as urea only from 2003 to 2006 equally as mentioned for soybean fertilizer.

Soybean was harvested each year in April and the grain yield was measured. Mechanical chiseling was carried out in September 2003, 2009 and 2013 using a chisel plow with seven shanks set on two parallel bars, and spaced $0.60 \mathrm{~m}$ from each other within the bars, resulting in effective $0.30 \mathrm{~m}$ between-drill spacing. The shanks were inclined forward forming a $25^{\circ}$ angle, and the effective action depth was around $0.30 \mathrm{~m}$. A cylinder was attached to the equipment to break up the biggest clods and smooth the soil surface to avoid harrowing. These subplots were kept unplanted between the winter and summer crops, and weeds were controlled using herbicides and hand weeding.

\subsection{Soil sample collection and analysis}

Undisturbed soil samples were taken after desiccation of the spring cover crops (before soybean planting) in 2003, 2005, and 2011 using a $5.0 \mathrm{~cm}$ high and $4.8 \mathrm{~cm}$ internal diameter cylinder, to determine soil bulk density, total porosity, macroporosity, and microporosity. Trenches approximately $0.40 \mathrm{~m}$ wide, $0.50 \mathrm{~m}$ long, and $0.80 \mathrm{~m}$ deep were opened. Samples were taken at the center of the $0.00-0.10,0.10-0.20,0.20-0.40$, and $0.40-0.60 \mathrm{~m}$ depths using a steel support to force the volumetric ring into the soil. The soil cores were sealed with plastic lids to prevent damage and stored at $2{ }^{\circ} \mathrm{C}$. Then the soil samples were placed to saturate in plastic trays with water up to $2 / 3$ of the cylinder height. To prevent soil loss, the bottom of the cylinder was wrapped with polyester fabric. The samples were weighed after $48 \mathrm{~h}$ of immersion to determine the saturated weight. Then the cylinders were set on a tension table (Dane and Hopmans, 2002), submitted to a tension of $0.006 \mathrm{MPa}$, and wet weight was recorded. After this, the samples were dried in a forced air oven at $105^{\circ} \mathrm{C}$ for $48 \mathrm{~h}$ and the dry soil mass was determined. Bulk density (Bd) was calculated dividing the dry soil by the volume of the volumetric cylinder. Considering that the water in the macropores is removed at $0.006 \mathrm{MPa}$, the volume of micropores was determined (Danielson and Sutherland, 1986). Soil total porosity was calculated considering the difference between saturated and dry soil mass, plus the sample volume. Macroporosity was obtained by calculating the difference between the total porosity and microporosity.

Soil samples for soil aggregate analyses were collected on $12 / 14 / 2011$, after desiccation of the spring cover crops. Trenches $0.30 \mathrm{~m}$ wide, $0.40 \mathrm{~m}$ long, and $0.30 \mathrm{~m}$ deep were opened in each plot, and monoliths $0.10 \mathrm{~m}$ deep, $0.20 \mathrm{~m}$ long, and $0.10 \mathrm{~m}$ wide were taken at depths of $0-0.10$ and $0.10-0.20 \mathrm{~m}$. The samples were placed in plastic bags, air-dried and then passed through 8 and $4 \mathrm{~mm}$ sieves. The portion retained in the $4 \mathrm{~mm}$ sieve was used for analysis. Soil aggregate stability was determined as in Kemper and Chepil (1965). Two $25 \mathrm{~g}$ sub-samples were weighed, one was used for moisture determination by the gravimetric method (Gardner, 1986), and the other was wet-sieved. The subsamples for sieving were lightly pre-wetted with a sprinkler and left at room temperature for $10 \mathrm{~min}$. Then they were transferred to a set of sieves of $2.00,1.00,0.50,0.25$, and $0.105 \mathrm{~mm}$ diameter fixed to a vertical oscillation unit (Yoder, 1936). Sieving was performed with vertical oscillation ( 30 cycles per minute and $0.035 \mathrm{~m}$ ) of the set of sieves immersed in water for $15 \mathrm{~min}$. The portions retained on each sieve were transferred to aluminum pots with the aid of water and dried at $105^{\circ} \mathrm{C}$ for $24 \mathrm{~h}$. The percentage of aggregates retained on the $2.00 \mathrm{~mm}$ sieve (aggregates greater than $2.00 \mathrm{~mm}$ ), the mean weight diameter (MWD), and the mean geometric diameter (MGD) were determined. We also calculated the aggregate stability index (ASI) as in Castro Filho et al. (2002).

\subsection{Soybean yields}

Soybean was harvested every year in April, except in 2008 and 2009 , when crops were lost. In each subplot, three lines of $8.0 \mathrm{~m}$ each were mechanically harvested with a plot combine harvester (NM Elite, Wintersteiger Seed Mech) and yields were adjusted to $13 \%$ humidity. Then the relative yields were calculated, considering the chiseled plots $100 \%$.

\subsection{Statistical analysis}

The results were submitted to ANOVA and means were compared by the Fisher's Least Significant Difference (LSD, $\mathrm{P}<0.05$ ), using the statistical software SAS version 9.2 (SAS Institute Inc, 2009).

\section{Results}

No significant interactions of the fall-winter and cover crops were observed for evaluation of soil physical proprieties and soybean yield. In 2003 and 2005 there was no effect of the fallwinter crops on soil physical properties to a depth of $0.60 \mathrm{~m}$ (Tables 4 and 5). However, in 2011 the lowest bulk density was observed in the $0.10-0.20 \mathrm{~m}$ layer with sunflower (Table 4). Chiseling resulted in higher soil total porosity and macroporosity in the $0-0.10 \mathrm{~m}$ layer in the first year, but there was no difference between the cover crop species (Table 4). Cover crops decreased soil compaction from 2005 onward. In two years, there was a decrease of $0.02 \mathrm{~m}^{3} \mathrm{~m}^{-3}$ in soil macroporosity at $0-0.10 \mathrm{~m}$ in chiseled plots uncropped in the spring (Table 5). Conversely, after two years and use of cover crops in 2003-2005, the volume of macropores increased $0.04 \mathrm{~m}^{3} \mathrm{~m}^{-3}$ (average of cover crops results) at the $0-0.10 \mathrm{~m}$ depth. However, in the 0.10-0.20 m layer, there was an increase of $0.05 \mathrm{~m}^{3} \mathrm{~m}^{-3}$ in soil macroporosity with fallow/chiseling treatment.

Despite general improvements in soil physical attributes observed with cover crops in the upper soil layer, the region with higher root colonization, in 2005 the best balance in the macro to micropore ratio was observed with sunn hemp in the $0.10-0.20 \mathrm{~m}$ layer, similar to the results obtained with chiseling. At the $0.20-0.40 \mathrm{~m}$ soil layer, sorghum, sunn hemp, and chiseling showed higher values of macroporosity and lower microporosity, an improved soil physical quality in depth. Similar results were observed in 2011 to a depth of $0.40 \mathrm{~m}$, when the use of cover crops led to soil quality level similar to chiseling. However, in the $0.40-0.60 \mathrm{~m}$ layer, below the chiseled layer, sunn hemp and pearl millet grown for nine consecutive years as cover crops decreased soil bulk density compared with chiseling (Table 6), probably due to root action. In 2011, soil aggregation was affected only by the 
Table 4

Soil bulk density, macroporosity, microporosity and total soil porosity at depths $0-0.10,0.10-0.20,0.20-0.40$ and $0.40-0.60 \mathrm{~m}$ in the first year of the experiment (2003), as affected by rotations/chiseling. Botucatu, Brazil.

\begin{tabular}{|c|c|c|c|c|}
\hline \multirow[t]{2}{*}{ Treatments } & \multicolumn{3}{|c|}{ Porosity $\left(\mathrm{m}^{3} \mathrm{~m}^{-3}\right)$} & \multirow[t]{2}{*}{ Bulk density $\left(\mathrm{g} \mathrm{cm}^{-}\right.$} \\
\hline & Total & Micro & Macro & \\
\hline & & & $0-0.10 \mathrm{~m}$ & \\
\hline \multicolumn{5}{|l|}{ Fall/winter crop } \\
\hline Sunflower & $0.51 \mathrm{a}^{\mathrm{a}}$ & $0.44 \mathrm{a}$ & $0.07 \mathrm{a}$ & $1.27 \mathrm{a}$ \\
\hline Triticale & $0.53 \mathrm{a}$ & $0.45 \mathrm{a}$ & $0.08 \mathrm{a}$ & $1.27 \mathrm{a}$ \\
\hline \multicolumn{5}{|l|}{ Cover crop } \\
\hline Pearl millet & $0.52 \mathrm{~B}$ & $0.44 \mathrm{~A}$ & $0.08 \mathrm{~B}$ & $1.28 \mathrm{~A}$ \\
\hline Forage sorghum & $0.49 \mathrm{~B}$ & $0.44 \mathrm{~A}$ & $0.05 \mathrm{~B}$ & $1.26 \mathrm{~A}$ \\
\hline Sunn hemp & $0.51 \mathrm{~B}$ & $0.45 \mathrm{~A}$ & $0.06 \mathrm{~B}$ & $1.30 \mathrm{~A}$ \\
\hline \multirow[t]{2}{*}{ Chiseling/Fallow } & $0.56 \mathrm{~A}$ & $0.43 \mathrm{~A}$ & $0.13 \mathrm{~A}$ & $1.25 \mathrm{~A}$ \\
\hline & \multicolumn{4}{|c|}{$0.10-0.20 \mathrm{~m}$} \\
\hline \multicolumn{5}{|l|}{ Fall/winter crop } \\
\hline Sunflower & $0.50 \mathrm{a}$ & $0.45 \mathrm{a}$ & $0.05 a$ & $1.29 \mathrm{a}$ \\
\hline Triticale & $0.52 \mathrm{a}$ & $0.45 \mathrm{a}$ & $0.07 \mathrm{a}$ & $1.26 \mathrm{a}$ \\
\hline \multicolumn{5}{|l|}{ Cover crop } \\
\hline Pearl millet & $0.51 \mathrm{~A}$ & $0.45 \mathrm{~A}$ & $0.06 \mathrm{~A}$ & $1.27 \mathrm{~A}$ \\
\hline Forage sorghum & $0.52 \mathrm{~A}$ & $0.45 \mathrm{~A}$ & $0.07 \mathrm{~A}$ & $1.27 \mathrm{~A}$ \\
\hline Sunn hemp & $0.49 \mathrm{~A}$ & $0.44 \mathrm{~A}$ & $0.05 \mathrm{~A}$ & $1.31 \mathrm{~A}$ \\
\hline Chiseling/Fallow & $0.52 \mathrm{~A}$ & $0.45 \mathrm{~A}$ & $0.07 \mathrm{~A}$ & $1.24 \mathrm{~A}$ \\
\hline & \multicolumn{4}{|c|}{$0.20-0.40 \mathrm{~m}$} \\
\hline \multicolumn{5}{|l|}{ Fall/winter crop } \\
\hline Sunflower & $0.53 \mathrm{a}$ & $0.45 \mathrm{a}$ & $0.08 \mathrm{a}$ & $1.26 \mathrm{a}$ \\
\hline Triticale & $0.53 \mathrm{a}$ & $0.48 \mathrm{a}$ & $0.05 a$ & $1.26 \mathrm{a}$ \\
\hline \multicolumn{5}{|l|}{ Cover crop } \\
\hline Pearl millet & $0.52 \mathrm{~A}$ & $0.46 \mathrm{~A}$ & $0.06 \mathrm{~A}$ & $1.27 \mathrm{~A}$ \\
\hline Forage sorghum & $0.54 \mathrm{~A}$ & $0.47 \mathrm{~A}$ & $0.07 \mathrm{~A}$ & $1.24 \mathrm{~A}$ \\
\hline Sunn hemp & $0.54 \mathrm{~A}$ & $0.47 \mathrm{~A}$ & $0.07 \mathrm{~A}$ & $1.26 \mathrm{~A}$ \\
\hline Chiseling/Fallow & $0.54 \mathrm{~A}$ & $0.47 \mathrm{~A}$ & $0.07 \mathrm{~A}$ & $1.27 \mathrm{~A}$ \\
\hline \multicolumn{5}{|c|}{$0.40-0.60 \mathrm{~m}$} \\
\hline \multicolumn{5}{|l|}{ Fall/winter crop } \\
\hline Sunflower & $0.56 \mathrm{a}$ & $0.46 a$ & $0.10 \mathrm{a}$ & $1.16 \mathrm{a}$ \\
\hline Triticale & $0.56 \mathrm{a}$ & $0.47 \mathrm{a}$ & $0.09 \mathrm{a}$ & $1.17 \mathrm{a}$ \\
\hline \multicolumn{5}{|l|}{ Cover crop } \\
\hline Pearl millet & $0.56 \mathrm{~A}$ & $0.48 \mathrm{~A}$ & $0.08 \mathrm{~A}$ & $1.19 \mathrm{~A}$ \\
\hline Forage sorghum & $0.57 \mathrm{~A}$ & $0.47 \mathrm{~A}$ & $0.10 \mathrm{~A}$ & $1.14 \mathrm{~A}$ \\
\hline Sunn hemp & $0.55 \mathrm{~A}$ & $0.47 \mathrm{~A}$ & $0.08 \mathrm{~A}$ & $1.16 \mathrm{~A}$ \\
\hline Chiseling/Fallow & $0.56 \mathrm{~A}$ & $0.46 \mathrm{~A}$ & $0.10 \mathrm{~A}$ & $1.17 \mathrm{~A}$ \\
\hline
\end{tabular}

a Means followed by different letters, lower-case letters within fall/winter crops and upper-case letters within cover crops differ from each other by the paired $t$-test (LSD, $\mathrm{P}<0.05$ ).
Table 5

Soil bulk density, macroporosity, microporosity and total soil porosity at depths $0-0.10,0.10-0.20,0.20-0.40$ and $0.40-0.60 \mathrm{~m}$ in the third year of the experiment (2005), as affected by rotations/chiseling. Botucatu, Brazil.

\begin{tabular}{|c|c|c|c|c|}
\hline \multirow[t]{2}{*}{ Treatments } & \multicolumn{3}{|c|}{ Porosity $\left(\mathrm{m}^{3} \mathrm{~m}^{-3}\right)$} & \multirow[t]{2}{*}{ Bulk density $\left(\mathrm{g} \mathrm{cm}^{-3}\right.$} \\
\hline & Total & Micro & Macro & \\
\hline & & & $0-0.10 \mathrm{~m}$ & \\
\hline \multicolumn{5}{|l|}{ Fall/winter crop } \\
\hline Sunflower & $0.54 \mathrm{a}^{\mathrm{a}}$ & $0.43 \mathrm{a}$ & $0.11 \mathrm{a}$ & $1.28 \mathrm{a}$ \\
\hline Triticale & $0.53 \mathrm{a}$ & $0.43 \mathrm{a}$ & $0.10 \mathrm{a}$ & $1.30 \mathrm{a}$ \\
\hline \multicolumn{5}{|l|}{ Cover crop } \\
\hline Pearl millet & $0.55 \mathrm{~A}$ & $0.44 \mathrm{~A}$ & $0.11 \mathrm{~A}$ & $1.28 \mathrm{~A}$ \\
\hline Forage sorghum & $0.53 \mathrm{~A}$ & $0.44 \mathrm{~A}$ & $0.09 \mathrm{~A}$ & $1.31 \mathrm{~A}$ \\
\hline Sunn hemp & $0.54 \mathrm{~A}$ & $0.42 \mathrm{~A}$ & $0.12 \mathrm{~A}$ & $1.29 \mathrm{~A}$ \\
\hline \multirow[t]{2}{*}{ Chiseling/Fallow } & $0.53 \mathrm{~A}$ & $0.42 \mathrm{~A}$ & $0.11 \mathrm{~A}$ & $1.27 \mathrm{~A}$ \\
\hline & \multicolumn{4}{|c|}{$0.10-0.20 \mathrm{~m}$} \\
\hline \multicolumn{5}{|l|}{ Fall/winter crop } \\
\hline Sunflower & $0.54 \mathrm{a}$ & $0.43 \mathrm{a}$ & $0.11 \mathrm{a}$ & $1.27 \mathrm{a}$ \\
\hline Triticale & $0.54 \mathrm{a}$ & $0.44 \mathrm{a}$ & $0.10 \mathrm{a}$ & $1.31 \mathrm{a}$ \\
\hline \multicolumn{5}{|l|}{ Cover crop } \\
\hline Pearl millet & $0.53 \mathrm{~A}$ & $0.44 \mathrm{~B}$ & $0.09 \mathrm{~B}$ & $1.30 \mathrm{~A}$ \\
\hline Forage sorghum & $0.55 \mathrm{~A}$ & $0.46 \mathrm{~A}$ & $0.09 \mathrm{~B}$ & $1.33 \mathrm{~A}$ \\
\hline Sunn hemp & $0.54 \mathrm{~A}$ & $0.42 \mathrm{C}$ & $0.12 \mathrm{~A}$ & $1.26 \mathrm{~A}$ \\
\hline Chiseling/Fallow & $0.54 \mathrm{~A}$ & $0.42 \mathrm{C}$ & $0.12 \mathrm{~A}$ & $1.27 \mathrm{~A}$ \\
\hline & \multicolumn{4}{|c|}{$0.20-0.40 \mathrm{~m}$} \\
\hline \multicolumn{5}{|l|}{ Fall/winter crop } \\
\hline Sunflower & $0.54 \mathrm{a}$ & $0.46 \mathrm{a}$ & $0.08 \mathrm{a}$ & $1.26 \mathrm{a}$ \\
\hline Triticale & $0.53 \mathrm{a}$ & $0.45 \mathrm{a}$ & $0.08 \mathrm{a}$ & $1.27 \mathrm{a}$ \\
\hline \multicolumn{5}{|l|}{ Cover crop } \\
\hline Pearl millet & $0.53 \mathrm{~A}$ & $0.47 \mathrm{~A}$ & $0.06 \mathrm{~B}$ & $1.27 \mathrm{~A}$ \\
\hline Forage sorghum & $0.54 \mathrm{~A}$ & $0.46 \mathrm{AB}$ & $0.08 \mathrm{AB}$ & $1.25 \mathrm{~A}$ \\
\hline Sunn hemp & $0.53 \mathrm{~A}$ & $0.45 \mathrm{~B}$ & $0.08 \mathrm{AB}$ & $1.28 \mathrm{~A}$ \\
\hline \multirow[t]{2}{*}{ Chiseling/Fallow } & $0.54 \mathrm{~A}$ & $0.44 \mathrm{~B}$ & $0.10 \mathrm{~A}$ & $1.24 \mathrm{~A}$ \\
\hline & \multicolumn{4}{|c|}{$0.40-0.60 \mathrm{~m}$} \\
\hline \multicolumn{5}{|l|}{ Fall/winter crop } \\
\hline Sunflower & $0.56 \mathrm{a}$ & $0.47 \mathrm{a}$ & $0.09 \mathrm{a}$ & $1.22 \mathrm{a}$ \\
\hline Triticale & $0.56 \mathrm{a}$ & $0.47 \mathrm{a}$ & $0.09 \mathrm{a}$ & $1.23 \mathrm{a}$ \\
\hline \multicolumn{5}{|l|}{ Cover crop } \\
\hline Pearl millet & $0.56 \mathrm{~A}$ & $0.46 \mathrm{~A}$ & $0.10 \mathrm{~A}$ & $1.22 \mathrm{~A}$ \\
\hline Forage sorghum & $0.56 \mathrm{~A}$ & $0.47 \mathrm{~A}$ & $0.09 \mathrm{~A}$ & $1.23 \mathrm{~A}$ \\
\hline Sunn hemp & $0.55 \mathrm{~A}$ & $0.46 \mathrm{~A}$ & $0.09 \mathrm{~A}$ & $1.22 \mathrm{~A}$ \\
\hline Chiseling/Fallow & $0.56 \mathrm{~A}$ & $0.47 \mathrm{~A}$ & $0.09 \mathrm{~A}$ & $1.22 \mathrm{~A}$ \\
\hline
\end{tabular}

a Means followed by different letters, lower-case letters within fall/winter crops and upper-case letters within cover crops differ from each other by the paired $t$-test (LSD, $\mathrm{P}<0.05$ ).

\section{Discussion}

A macroporosity of $0.13 \mathrm{~m}^{3} \mathrm{~m}^{-3}$ at $0-0.10 \mathrm{~m}$, obtained in the first year with chiseling (Table 4), was higher than the limit of $0.10 \mathrm{~m}^{3} \mathrm{~m}^{-3}$ established by Grable and Siemer (1968) as critical for optimal plant growth and resulted in higher soybean yields in 2003/2004 (Table 8). A higher macroporosity favors root growth, water infiltration and oxygen diffusion in the soil profile. At low oxygen availability, roots produce ethylene, which is toxic to plants (Gardner et al., 1999). In soybean, the lack of oxygen impairs symbiotic nitrogen fixation, further decreasing yields (Siczek and Lipiec, 2011). Maybe, this increase of soil macroporosity in the $0-0.10 \mathrm{~m}$ layer by chiseling justify the increase of the macroporosity in the $0.10-0.20 \mathrm{~m}$ layer two years later (Table 5), due to the greater growth of plant roots in depth.

In clay soils, a macroporosity below $0.10 \mathrm{~m}^{3} \mathrm{~m}^{-3}$ is commonly found due to the low specific surface of the particles. The probability of macroporosity reaching critical values in clay soils is higher under no-till due to the absence of tillage, which favors the natural accommodation of particles or by pressures exerted on the soil surface (Hamza and Anderson, 2005). Despite the increased macroporosity found at $0-0.10 \mathrm{~m}$ with chiseling in 2003 , there were no differences in soil bulk density (Table 4). It was expected that the effects of treatments on macroporosity would also be significant 
Table 6

Soil bulk density, macroporosity, microporosity and total soil porosity at depths $0-0.10,0.10-0.20,0.20-0.40$ and $0.40-0.60 \mathrm{~m}$ in the nineth year of the experiment (2011), as affected by rotations/chiseling. Botucatu, Brazil.

\begin{tabular}{|c|c|c|c|c|}
\hline \multirow[t]{2}{*}{ Treatment } & \multicolumn{3}{|c|}{ Porosity $\left(\mathrm{m}^{3} \mathrm{~m}^{-3}\right)$} & \multirow[t]{2}{*}{ Bulk density $\left(\mathrm{g} \mathrm{cm}^{-3}\right.$} \\
\hline & Total & Micro & Macro & \\
\hline & & & $0-0.10 \mathrm{~m}$ & \\
\hline \multicolumn{5}{|l|}{ Fall/winter crop } \\
\hline Sunflower & $0.48 \mathrm{a}^{\mathrm{a}}$ & $0.38 \mathrm{~b}$ & $0.10 \mathrm{a}$ & $1.35 \mathrm{a}$ \\
\hline Triticale & $0.49 \mathrm{a}$ & $0.39 a$ & $0.10 \mathrm{a}$ & $1.35 \mathrm{a}$ \\
\hline \multicolumn{5}{|l|}{ Cover crop } \\
\hline Pearl millet & $0.47 \mathrm{~A}$ & $0.38 \mathrm{AB}$ & $0.09 \mathrm{~B}$ & $1.34 \mathrm{~A}$ \\
\hline Forage sorghum & $0.48 \mathrm{~A}$ & $0.41 \mathrm{~A}$ & $0.09 \mathrm{~B}$ & $1.36 \mathrm{~A}$ \\
\hline Sunn hemp & $0.49 \mathrm{~A}$ & $0.37 \mathrm{~B}$ & $0.12 \mathrm{~A}$ & $1.32 \mathrm{~A}$ \\
\hline \multirow[t]{2}{*}{ Chiseling/Fallow } & $0.49 \mathrm{~A}$ & $0.39 \mathrm{AB}$ & $0.10 \mathrm{AB}$ & $1.38 \mathrm{~A}$ \\
\hline & \multicolumn{4}{|c|}{$0.10-0.20 \mathrm{~m}$} \\
\hline \multicolumn{5}{|l|}{ Fall/winter crop } \\
\hline Sunflower & $0.46 \mathrm{a}$ & $0.38 \mathrm{a}$ & $0.08 \mathrm{a}$ & $1.36 \mathrm{~b}$ \\
\hline Triticale & $0.46 \mathrm{a}$ & $0.37 \mathrm{a}$ & $0.09 \mathrm{a}$ & $1.40 \mathrm{a}$ \\
\hline \multicolumn{5}{|l|}{ Cover crop } \\
\hline Pearl millet & $0.48 \mathrm{~A}$ & $0.40 \mathrm{~A}$ & $0.08 \mathrm{~B}$ & $1.37 \mathrm{~A}$ \\
\hline Forage sorghum & $0.46 \mathrm{~A}$ & $0.38 \mathrm{~A}$ & $0.08 \mathrm{~B}$ & $1.37 \mathrm{~A}$ \\
\hline Sunn hemp & $0.48 \mathrm{~A}$ & $0.37 \mathrm{~A}$ & $0.11 \mathrm{~A}$ & $1.37 \mathrm{~A}$ \\
\hline Chiseling/Fallow & $0.46 \mathrm{~A}$ & $0.37 \mathrm{~A}$ & $0.09 \mathrm{AB}$ & $1.40 \mathrm{~A}$ \\
\hline & \multicolumn{4}{|c|}{$0.20-0.40 \mathrm{~m}$} \\
\hline \multicolumn{5}{|l|}{ Fall/winter crop } \\
\hline Sunflower & $0.48 \mathrm{a}$ & $0.39 a$ & $0.09 \mathrm{a}$ & $1.29 \mathrm{a}$ \\
\hline Triticale & $0.47 \mathrm{a}$ & $0.39 \mathrm{a}$ & $0.08 \mathrm{a}$ & $1.30 \mathrm{a}$ \\
\hline \multicolumn{5}{|l|}{ Cover crop } \\
\hline Pearl millet & $0.49 \mathrm{~A}$ & $0.41 \mathrm{~A}$ & $0.08 \mathrm{AB}$ & $1.30 \mathrm{~A}$ \\
\hline Forage sorghum & $0.47 \mathrm{~A}$ & $0.40 \mathrm{AB}$ & $0.07 \mathrm{~B}$ & $1.30 \mathrm{~A}$ \\
\hline Sunn hemp & $0.48 \mathrm{~A}$ & $0.40 \mathrm{AB}$ & $0.08 \mathrm{AB}$ & $1.29 \mathrm{~A}$ \\
\hline \multirow[t]{2}{*}{ Chiseling/Fallow } & $0.48 \mathrm{~A}$ & $0.37 \mathrm{~B}$ & $0.11 \mathrm{~A}$ & $1.30 \mathrm{~A}$ \\
\hline & \multicolumn{4}{|c|}{$0.40-0.60 \mathrm{~m}$} \\
\hline \multicolumn{5}{|l|}{ Fall/winter crop } \\
\hline Sunflower & $0.50 \mathrm{a}$ & $0.42 \mathrm{a}$ & $0.08 \mathrm{a}$ & $1.26 \mathrm{a}$ \\
\hline Triticale & $0.49 \mathrm{a}$ & $0.41 \mathrm{a}$ & $0.08 \mathrm{a}$ & $1.27 \mathrm{a}$ \\
\hline \multicolumn{5}{|l|}{ Cover crop } \\
\hline Pearl millet & $0.50 \mathrm{~A}$ & $0.43 \mathrm{~A}$ & $0.07 \mathrm{~A}$ & $1.24 \mathrm{~B}$ \\
\hline Forage sorghum & $0.48 \mathrm{~A}$ & $0.41 \mathrm{AB}$ & $0.07 \mathrm{~A}$ & $1.28 \mathrm{AB}$ \\
\hline Sunn hemp & $0.48 \mathrm{~A}$ & 0.39 B & $0.09 \mathrm{~A}$ & $1.23 \mathrm{~B}$ \\
\hline Chiseling/Fallow & $0.49 \mathrm{~A}$ & $0.43 \mathrm{~A}$ & $0.07 \mathrm{~A}$ & $1.32 \mathrm{~A}$ \\
\hline
\end{tabular}

a Means followed by different letters, lower-case letters within fall/winter crops and upper-case letters within cover crops differ from each other by the paired $t$-test (LSD, $\mathrm{P}<0.05$ ).

on soil density. However this was not observed. According to Evans et al. (1996), soil bulk density as determined in the present study is not highly sensitive to soil chiseling, and has been considered an unreliable parameter to detect soil compaction (Calonego and Rosolem, 2011).

While chiseling resulted in better immediate results on soil structure, which did not last up to the second year, the beneficial effect of cover crops was observed in the medium term, leading to soybean yields equal or higher than chiseling. This is the result of a re-accommodation of soil particles in the pore space result-
Table 7

Soil agregate stability at depths $0-0.10$ and $0.10-0.20 \mathrm{~m}$ as affected by crop rotations/chiseling, in 2011. Botucatu, Brazil.

\begin{tabular}{|c|c|c|c|c|}
\hline \multirow[t]{2}{*}{ Treatament } & Aggregates $^{\mathrm{a}}$ & $\mathrm{MWD}^{\mathrm{b}}$ & $\mathrm{GMD}^{\mathrm{c}}$ & $\mathrm{ASI}^{\mathrm{d}}$ \\
\hline & $\left(\mathrm{gg}^{-1}\right)$ & \multicolumn{2}{|l|}{$(\mathrm{mm})$} & $(\%)$ \\
\hline & \multicolumn{4}{|c|}{$0-0.10 \mathrm{~m}$} \\
\hline \multicolumn{5}{|l|}{ Fall/winter crop } \\
\hline Sunflower & $0.90 \mathrm{a}^{\mathrm{e}}$ & $2.76 \mathrm{a}$ & $2.44 \mathrm{a}$ & $96.51 \mathrm{a}$ \\
\hline Triticale & $0.91 \mathrm{a}$ & $2.80 \mathrm{a}$ & $2.51 \mathrm{a}$ & $97.25 \mathrm{a}$ \\
\hline \multicolumn{5}{|l|}{ Cover crop } \\
\hline Pearl millet & $0.91 \mathrm{~A}$ & $2.79 \mathrm{~A}$ & $2.51 \mathrm{AB}$ & $97.01 \mathrm{AB}$ \\
\hline Forage sorghum & $0.93 \mathrm{~A}$ & $2.84 \mathrm{~A}$ & $2.63 \mathrm{~A}$ & $97.77 \mathrm{~A}$ \\
\hline Sunn hemp & $0.87 \mathrm{~A}$ & $2.70 \mathrm{~A}$ & $2.31 \mathrm{~B}$ & $95.54 \mathrm{~B}$ \\
\hline \multirow[t]{2}{*}{ Chiselling/Fallow } & $0.91 \mathrm{~A}$ & $2.78 \mathrm{~A}$ & $2.52 \mathrm{AB}$ & $97.20 \mathrm{~A}$ \\
\hline & \multicolumn{4}{|c|}{$0.10-0.20 \mathrm{~m}$} \\
\hline \multicolumn{5}{|l|}{ Fall/winter crop } \\
\hline Sunflower & $0.85 \mathrm{a}$ & $2.68 \mathrm{a}$ & $2.32 \mathrm{a}$ & $96.16 \mathrm{a}$ \\
\hline Triticale & $0.85 \mathrm{a}$ & $2.68 \mathrm{a}$ & $2.35 \mathrm{a}$ & $96.55 \mathrm{a}$ \\
\hline \multicolumn{5}{|l|}{ Cover crop } \\
\hline Pearl millet & $0.88 \mathrm{~A}$ & $2.72 \mathrm{~A}$ & $2.41 \mathrm{~A}$ & $96.63 \mathrm{~A}$ \\
\hline Forage sorghum & $0.84 \mathrm{~A}$ & $2.65 \mathrm{~A}$ & $2.31 \mathrm{~A}$ & $96.44 \mathrm{~A}$ \\
\hline Sunn hemp & $0.86 \mathrm{~A}$ & $2.68 \mathrm{~A}$ & $2.32 \mathrm{~A}$ & $96.11 \mathrm{~A}$ \\
\hline Chiselling/Fallow & $0.84 \mathrm{~A}$ & $2.66 \mathrm{~A}$ & $2.29 \mathrm{~A}$ & $96.24 \mathrm{~A}$ \\
\hline
\end{tabular}

a Aggregates $>2 \mathrm{~mm}$.

b Mean weight diameter.

c Geometric mean diameter.

d Aggregate stability index.

e Means followed by different letters, lower-case letters within fall/winter crops and upper-case letters within spring crops differ from each other by the paired $t$-test (LSD, P < 0.05).

ing in soil compaction. Hence, over time a new chiseling operation would be necessary. The effect of chiseling on soil macroporosity is ephemeral because of particle reconsolidation under successive wetting-drying cycles (Abreu et al., 2004). Conversely, the rotation with cover crops enhances soil physical quality (Castro et al., 2011), as observed in the present experiment, particularly with sunn hemp increasing macroporosity (Tables 5 and 6), and forage sorghum increasing aggregate stability (Table 7). Kooistra and Tovey (1994) emphasize that soil compaction can occur with increased microporosity and decreased macroporosity, resulting in lower total porosity. This finding was confirmed in this experiment in 2011, when the volume of micropores in the $0-0.10 \mathrm{~m}$ layer was lower in plots with sunn hemp as a cover crop (Table 6).

According to Garcia et al. (2012), crops such as forage grasses, pearl millet, and sorghum-sudangrass can ameliorate soil quality by growing roots in these upper layers with greater penetration resistance. Rosolem et al. (2002) observed a higher root length in the soil profile below the compacted layer for pearl millet while sunn hemp had the lower root growth. However, the grasses were more sensitive to higher soil penetration resistance compared to legumes.

Thus, the use of plants that have aggressive and vigorous roots, with the capacity to grow in compacted soils have improved the

Table 8

Soybean grain yield means and annual relative grain yields determined over 12-years experimental period as affected by cover crops grown in spring. Botucatu, Brazil.

\begin{tabular}{|c|c|c|c|c|c|c|c|c|c|c|c|}
\hline \multirow[t]{2}{*}{ Year $^{\mathrm{a}}$} & $2003 / 04$ & $2004 / 05$ & $2005 / 06$ & $2006 / 07$ & $2009 / 10$ & $2010 / 11$ & $2011 / 12$ & $2012 / 13$ & $2013 / 14$ & $2014 / 15$ & Mean $^{\mathrm{b}, \mathrm{c}}$ \\
\hline & \multicolumn{10}{|c|}{ Relative yield (\%) ${ }^{\mathrm{b}}$} & $\mathrm{kg} \mathrm{ha}^{-1}$ \\
\hline \multicolumn{12}{|l|}{ Cover crop } \\
\hline Pearl millet & $90 \mathrm{ab}$ & $102 \mathrm{ab}$ & $99 \mathrm{a}$ & $111 \mathrm{a}$ & $102 \mathrm{a}$ & $104 \mathrm{ab}$ & $90 \mathrm{bc}$ & $91 \mathrm{~b}$ & $86 \mathrm{~b}$ & $132 \mathrm{a}$ & 2869 b \\
\hline Sorghum & $78 \mathrm{~b}$ & $91 \mathrm{~b}$ & $100 \mathrm{a}$ & $109 a b$ & $97 \mathrm{a}$ & $106 \mathrm{ab}$ & $88 \mathrm{c}$ & $99 \mathrm{a}$ & $97 \mathrm{ab}$ & $123 \mathrm{~b}$ & $2805 b$ \\
\hline Sunn hemp & $89 a b$ & $112 \mathrm{a}$ & $105 \mathrm{a}$ & $110 \mathrm{a}$ & 99 a & $111 \mathrm{a}$ & $98 \mathrm{ab}$ & $101 \mathrm{a}$ & $106 a$ & $127 \mathrm{ab}$ & 3000 a \\
\hline Chiseling & $100 \mathrm{a}$ & $100 \mathrm{~b}$ & $100 \mathrm{a}$ & $100 \mathrm{~b}$ & $100 \mathrm{a}$ & $100 \mathrm{~b}$ & $100 \mathrm{a}$ & $100 \mathrm{a}$ & $100 \mathrm{a}$ & $100 \mathrm{c}$ & 2817 b \\
\hline Yield (100\%) kg ha ${ }^{-1}$ & 2275 & 2900 & 3787 & 3294 & 3963 & 3008 & 3039 & 3203 & 1870 & 3202 & \\
\hline
\end{tabular}

a Soybean yield was not measured in 2007/08 and 2008/09 years.

b Data followed by different letters differ from each other by the paired $t$-test (LSD, $\mathrm{P}<0.05$ ).

c The mean soybean yields $\left(\mathrm{kg} \mathrm{ha}^{-1}\right)$ were compared by using the mean yield from the 10 harvests of each replicate. 
physical quality of the soil and benefit subsequent crops, such as soybean (Calonego and Rosolem, 2010). The roots are a source of mucilage and OM that acts directly on the aggregates stability due to the cementing and agglutinating function on soil mineral particles (Martins et al., 2009; Wendling et al., 2005). In addition, SOM stimulates the microbial population growth, which is important in the formation of macroaggregates (Tisdall and Oades, 1982). Besides, the roots promote the approximation and cohesion between the solid particles of the soil as it exerts biophysical pressures (axial and radial), and also by the drying in the adjacent region to the roots, resulting in a soil with a higher flocculation state (Gardner et al., 1999). Under these conditions, the proportion of macroaggregates will be higher than of microaggregates, consequently increasing macroporosity (Dexter, 1988) and reducing the compaction (Abdollahi et al., 2014). Hubbard et al. (2013) related that when sunn hemp was included in the rotation as a late summer cover crop, it added significantly more $\mathrm{C}$ to the soil than cropping systems with fallow in this period, improving soil physical proprieties. According to Raphael et al. (2016), the soil concentration of SOM and its fractions were higher under crop rotations with higher nitrogen input, especially where sunn hemp was grown in spring, in an experiment carried out in the same experimental area and with the same treatments of the present experiment.

Occasional chiseling was effective in maintaining high soybean yields for some time, but after 9 or 10 years yields observed in rotation with cover crops, and without chiseling were higher. Calonego and Rosolem (2010) reported that cover crops left biopores in the soil profile, enhancing water infiltration and soybean root growth in depth. Besides, after 10 years, crop rotations resulted in better soil compared with chiseling (Raphael et al., 2016), because there was more soil organic matter accumulated up to $10 \mathrm{~cm}$ deep in the soil.

Root growth in the soil profile favors particle aggregation and so the remediation of degraded or compacted soils (Castro et al., 2011; Garcia and Rosolem, 2010). Thus, grasses, due to a higher root length density, better distribution of the root system and root exudates (Calonego and Rosolem, 2010) would be better options to be used to improve soil structure. However, the higher soil aggregate stability observed with forage sorghum as compared with sunn hemp has not resulted in higher soybean grain yields, probably because under sunn hemp the soil still had over $95 \%$ of aggregates greater than $250 \mu \mathrm{m}$, i.e., macroaggregates (Oades and Waters, 1991). Moreover, it has been reported that sorghum may impair soybean growth through the exudation of the allelochemical sorgoleone (Weston et al., 2013).

Therefore, considering the results from the second soybean crop, mechanical management of soil compaction would not be the best option, since it can be substituted by cover crops, especially sunn hemp, which resulted in an average increase of $183 \mathrm{~kg} \mathrm{ha}^{-1}$ in soybean yields in 10 seasons. One of the factors explaining this increase is an increased soil macroporosity, which was very low at the beginning of the experiment.

\section{Conclusions}

Chiseling results in better immediate results on soil structure and soybean yields, but such benefits do not last up to the second year, while the beneficial effect of cover crops are observed in the medium and long term, leading to soybean yields equal or higher than occasional chiseling. Besides, in the long-term, the use of cover crops improves soil structure in deeper layers as compared with chiseling.

Sunn hemp is an interesting species to be included in rotation due to its capacity to increase soil macroporosity in clay soils with poor aeration.

\section{Acknowledgments}

This research was funded by FAPESP (The State of São Paulo Research Foundation).

\section{References}

Abdollahi, L., Munkholm, L.J., Garbout, A., 2014. Tillage system and cover crop effects on soil quality: II: Pore characteristics. Soil Sci. Soc. Am. J. 78, 271-279, http://dx.doi.org/10.2136/sssaj2013.07.0302.

Abreu, S.L., Reichert, J.M., Reinert, D.J., 2004. Mechanical and biological chiseling to reduce compaction of a sandy loam alfisol under no-tillage. Rev. Bras. Cienc. Solo 28, 519-531, http://dx.doi.org/10.1590/S0100-06832004000300013.

Busscher, W.J., Bauer, P.J., Frederick, J.R., 2002. Recompaction of a coastal loamy sand after deep tillage as a function of subsequent cumulative rainfall. Soil Tillage Res. 68, 49-57, http://dx.doi.org/10.1016/S0167-1987(02)00083-1.

Calonego, J.C., Rosolem, C.A., 2008. Soil aggregate stability after management with crop rotation and chiseling. Rev. Bras. Cienc. Solo 32, 1399-1407, http://dx.doi. org/10.1590/S0100-06832008000400004 (in Portuguese, with English abstract).

Calonego, J.C., Rosolem, C.A., 2010. Soybean root growth and yield in rotation with cover crops under chiseling and no-till. Eur. J. Agron. 33, 242-249, http://dx. doi.org/10.1016/j.eja.2010.06.002.

Calonego, J.C., Rosolem, C.A., 2011. Least Limiting Water Range in soil under crop rotations and chiseling. Rev. Bras. Cienc. Solo 35, 759-771, http://dx.doi.org/ 10.1590/S0100-06832011000300012.

Castro Filho, C., Lourenço, A., Guimarães, M.F., Fonseca, I.C.B., 2002. Aggregate stability under different soil management systems in a red latosol in the state of Parana, Brazil. Soil Tillage Res. 65, 45-51, http://dx.doi.org/10.1016/S01671987(01)00275-6.

Castro, G.S.A., Calonego, J.C., Crusciol, C.A.C., 2011. Soil physical properties in crop rotation systems as affected by liming materials. Pesq. Agropec. Bras. 46, 1690-1698, http://dx.doi.org/10.1590/S0100-204X2011001200015 (in Portuguese, with English abstract).

Castro, G.S.A., Crusciol, C.A.C., Calonego, J.C., Rosolem, C.A., 2015. Management impacts on soil organic matter of tropical soils. Vadose Zone J. 14, http://dx.doi. org/10.2136/vzj2014.07.0093.

Chen, G., Weil, R.R., Hill, R.L., 2014. Effects of compaction and cover crops on soil least limiting water range and air permeability. Soil Tillage Res. 136, 61-69, http://dx.doi.org/10.1016/j.still.2013.09.004.

Dane, J.H., Hopmans, J.W., 2002. Water retention and storage. In: Dane, J.H., Topp, G.C. (Eds.), Methods of Soil Analysis. Part 4. Physical Methods, SSSA Book Ser. 5.4. Soil Science Society of America, Madison, WI, pp. 671-720, http://dx.doi. org/10.2136/sssabookser5.4.c24.

Danielson, R.E., Sutherland, P.L., 1986. Porosity. In: Klute, A. (Ed.), Methods of Soil Analysis. Part 1. Physical and Mineralogical Methods. SSSA Book Ser. 5.1. SSSA. ASA, Madison, WI, pp. 443-461, http://dx.doi.org/10.2136/sssabookser5.1.2ed. c18.

Dexter, A.R., 1988. Advances in characterization of soil structure. Soil Till. Res. 11, 199-238, http://dx.doi.org/10.1016/0167-1987(88)90002-5.

Embrapa, 1997. Manual De métodos De Análises De Solo, 2nd ed. Centro Nacional de Pesquisa de Solos, Rio de Janeiro, Brazil.

Evans, S.D., Lindstrom, M.J., Voorhees, W.B., Mocrief, J.F., Nelson, G.A., 1996. Effect of subsoiling and subsequent tillage on soil bulk density, soil moisture and corn yield. Soil Tillage Res. 38, 35-46, http://dx.doi.org/10.1016/01671987(96)01020-3.

Garcia, R.A., Rosolem, C.A., 2010. Aggregates in a Rhodic Ferralsol under no-tillage and crop rotation. Pesqui. Agropecu. Bras. 45, 1489-1498, http://dx.doi.org/10. 1590/S0100-204X2010001200021 (in Portuguese, with English abstract).

Garcia, R.A., Li, Y., Rosolem, C.A., 2012. Soil organic matter and physical attributes affected by crop rotation under no-till. Soil Sci. Soc. Am. J. 77, 1724-1731, http://dx.doi.org/10.2136/sssaj2012.0310.

Gardner, C.M.K., Laryea, K.B., Unger, P.W., 1999. Soil physical constraints to plant growth and crop production. In: Land and Water Development Division. Food and Agriculture Organization of the United Nations, Rome.

Gardner, W.H., 1986. Water content. In: Klute, A. (Ed.), Methods of Soil Analysis. Part 1. Physical and Mineralogical Methods., 2nd ed. American Society of Agronomy, Madison, WI, pp. 493-541.

Grable, A.R., Siemer, E.G., 1968. Effects of bulk density, aggregate size, and soil water suction on oxygen diffusion, redox potential and elongation of corn roots. Soil Sci. Soc. Am. J. 32, 180-186, http://dx.doi.org/10.2136/sssaj1968. $03615995003200020011 x$.

Hamza, M.A., Anderson, W.K., 2005. Soil compaction in cropping systems: a review of the nature, causes and possible solutions. Soil Tillage Res. 82, 121-145, http://dx.doi.org/10.1016/j.still.2004.08.009.

Hubbard, R.K., Strickland, T.C., Phatak, S., 2013. Effects of cover crop systems on soil physical properties and carbon/nitrogen relationships in the coastal plain of southeastern USA. Soil Tillage Res. 126, 276-283, http://dx.doi.org/10.1016/ j.still.2012.07.009.

Kemper, W.D., Chepil, W.S., 1965. Size distribution of aggregates. In: Black, C.A., Evans, D.D., White, J.L., Jesminger, L.E., Clark, F.E. (Eds.), Methods of Soil Analysis. American Society of Agronomy, Madison, WI, pp. 499-510. 
Kooistra, M.J., Tovey, N.K., 1994. Effects of compaction on soil microstructure. In: Soane, B.D., van Ouwerkerk, C. (Eds.), Soil Compaction in Crop Production. Elsevier, Amsterdam, pp. 91-112.

Marschner, H., 1995. Mineral Nutrition of Higher Plants, 2nd ed. Academic Press, London.

Martins, M.R., Corá, J.E., Jorge, R.F., Marcelo, A.V., 2009. Crop type influences soil aggregation and organic matter under no-tillage. Soil Tillage Res. 104, 22-29, http://dx.doi.org/10.1016/j.still.2008.11.003.

Oades, J.M., Waters, A.G., 1991. Aggregate hierarchy in soils. Aust. J. Soil Res. 29, 815-828, http://dx.doi.org/10.1071/SR9910815.

Raij, B., Andrade, J.C., Cantarella, H., Quaggio, J.A., 2001. Análise Química Para Avaliação Da Fertilidade De Solos Tropicais. Instituto Agronômico de Campinas, Campinas.

Raphael, J.P.A., Calonego, J.C., Milori, D.M.B.P., Rosolem, C.A., 2016. Soil organic matter in crop rotations under no-till. Soil Tillage Res. 155, 45-53, http://dx. doi.org/10.1016/j.still.2015.07.020.

Rosolem, C.A., Foloni, J.S.S., Tiritan, C.S., 2002. Root growth and nutrient accumulation in cover crops as affected by soil compaction. Soil Tillage Res. 65, 109-115, http://dx.doi.org/10.1016/S0167-1987(01)00286-0.

SAS Institute Inc, 2009. The SAS System for Windows. SAS 9.2. SAS Inst., Cary, NC.

Siczek, A., Lipiec, J., 2011. Soybean nodulation and nitrogen fixation in response to soil compaction and surface straw mulching. Soil Tillage Res. 114, 50-56, http://dx.doi.org/10.1016/j.still.2011.04.001.
Soane, B.D., van Ouwerkerk, C., 1995. Implications of soil compaction in crop production for the quality of the environment. Soil Tillage Res. 35, 5-22, http:// dx.doi.org/10.1016/0167-1987(95)00475-8.

Soil Survey Staff, 2014. Keys to Soil Taxonomy, 12th ed. USDA-Natural Resources Conservation Service, Washington, DC

Tisdall, J.M., Oades, J.M., 1982. Organic matter and water-stable aggregates in soils. Eur. J. Soil Sci. 33, 141-163, http://dx.doi.org/10.1111/j.1365-2389.1982. tb01755.x.

Wendling, B., Jucksch, I., Mendonça, E.S., Neves, J.C.L., 2005. Carbono organico e estabilidade de agregados de um Latossolo Vermelho sob diferentes manejos. Pesq. Agropec. Bras. 40, 487-494, http://dx.doi.org/10.1590/S010006832008000700028.

Weston, L.A., Alsaadawi, I.S., Baerson, S.R., 2013. Sorghum allelopathy-from ecosystem to molecule. J. Chem. Ecol. 39 (2), 142-153, http://dx.doi.org/10. 1007/s10886-013-0245-8.

Yoder, R.E., 1936. A direct method of aggregate analysis of soils and a study of the physical nature of erosion losses. J. Am. Soc. Agron. 28, 337-351. 